\title{
Property Insurance for Iowa Farmers: The Rise of the Mutuals
}

\author{
JACK LUFKIN
}

"WHY should the farmers of Iowa pay into the coffers of rich corporations," a promoter of mutual insurance asked in a farm publication in 1894, "when they can get better protection in their own Mutual association. . . A man who carries his risks in the Farmers Mutuals is not only helping to break the power of eastern companies and saving himself money, but ... he is helping to tide over difficulty his unfortunate neighbor. ${ }^{11}$ This kind of rhetoric, in full flower by the 1890s, sustained the movement to promote mutual insurance from the 1870 s at least into the 1920s.

The spread of mutual insurance in Iowa in the last quarter of the nineteenth century represents part of a complex struggle between the forces of localism and the advance of Gilded Age business values into rural America. Early promoters of mutual insurance urged farmers to resist the incursions of eastern stock insurance companies. Thus, mutual insurance companies that were owned and operated by farmers originally formed to capitalize on farmers' desires to preserve local control. Gradually, however, leaders of the mutual movement came to realize the benefits of providing more specialized coverage and spreading risks among broader segments of the population. Consequently, the mutuals yielded increasingly to the "big business" practices that were infusing much of American economic life by the turn of the century-practices that local

1. Western Farmers' Institute, April 1894.

THE ANNALS OF IOWA 54 (Winter 1995). CThe State Historical Society of Iowa, 1995. 
mutuals ironically had originally been designed to counter. At the same time, however, the leaders of the mutual insurance movement continued to employ populist rhetoric. They were able to do so at least in part because of the tangible benefits they provided and because their claims continued to ring true for members of the mutual associations.

Thus, the development of mutual insurance companies in Iowa demonstrates how their leaders adapted to increasingly complex economic forces affecting farmers while at the same time accommodating the farmers' valued sense of localism and community cooperation during the mutuals' formative years. The ideological support and institutional base that developed from the mid-1870s to the early 1900 s laid the foundation for mutual insurance to become a dominant property insurance force in rural Iowa.

PRIOR TO THE CIVIL WAR, few Iowa farmers carried insurance. Inexpensive land, buildings, and equipment and small if any stock herds limited the financial risk posed by fire, hail, and windstorms. Although there were few defenses against natural calamities, informal kin and community support networksneighbors helping neighbors-helped farmers recover from losses. Pioneers could saw down trees and build back destroyed homes, barns, and other buildings. A payment from an insurance company would be of little use in a remote area having few suppliers or builders on hand. Thus, property insurance in the frontier farm setting was not a practical way to protect against risk. ${ }^{2}$

After the Civil War, Iowa's market economy expanded dramatically. Iowa farmers vastly increased their production capacity, and their market system became much broader and more complex and diversified. To meet the demands of the new markets, farmers increased their investments in land, buildings, equipment, and livestock. With more to lose from

2. Earle Ross, Iowa Agriculture: An Historical Suroey (Iowa City, 1951), 12-15, 20-23. On the importance of kin and community support networks, see, for example, John Mack Faragher, Sugar Creek: Life on the Illinois Prairie (New Haven, CT, 1986). 
fire and weather disturbances, property insurance became more attractive. ${ }^{3}$

Established insurance companies quickly stepped in to capitalize on the new opportunity. The companies that agressively sought to capture the Iowa market after the Civil War were among the earliest of the large-scale centralized institutions that played such a key role in the social and economic transformation of the United States in the last third of the nineteenth century. Large companies from New York City and Hartford, Connecticut, became leading insurers in the Hawkeye state. The Hartford, The Aetna, and The Phoenix, for example, all had Iowa agents. All of these companies were incorporated entities supported by stockholders who expected to share in profits generated by the companies' operations. ${ }^{4}$

Although these insurance companies brought clear benefits to Iowa farmers, they soon came under attack from local farmers. Some of the attacks were certainly justified. Eastern insurance

3. See, for example, R. Douglas Hurt, American Agriculture: A Brief History (Ames, 1994), 194-203, 216-17. Historians of American agriculture have been preoccupied in recent years with debating the nuances of this "capitalist transformation," in contrast to what they see as the overly simplistic earlier model (in, for example, Ross, Iowa Agriculture, 71-93, 116) of transformation from subsistence to commercial agriculture. For the major shapers of the terms of the debate, see, for example, James A. Henretta, "Families and Farms: Mentalité in Pre-Industrial America," William and Mary Quarterly 35 (1978), 3-32; Michael Merrill, "Cash is Good to Eat: Self-Sufficiency and Exchange in the Rural Economy of the United States," Radical History Review 3 (1977), 42-71; Steven Hahn and Jonathan Prude, eds., The Countryside in the Age of Capitalist Transformation (Chapel Hill, NC, 1985); Christopher Clark, The Roots of Rural Capitalism: Western Massachusetts, 1780-1860 (Ithaca, NY, 1990); Hal S. Barron, "Listening to the Silent Majority: Change and Continuity in the Nineteenth-Century Rural North," in Agriculture and National Development, ed. Lou Ferleger (Ames, 1990), 3-25; idem, "Old Wine in New Bottles? The Perspective of Rural History," in Outstanding in His Field: Perspectives on American Agriculture in Honor of Wayne D. Rasmussen, ed. Frederick V. Carstensen, Morton Rothstein, and Joseph A. Swanson (Ames, 1993); and Allan Kulikoff, The Agrarian Origins of American Capitalism (Charlottesville, VA, 1992). See also chap. 3, "Pricing the Future: Grain," in William Cronon, Nature's Metropolis: Chicago and the Great West (New York, 1991).

4. "A City Built on Risk," exhibition catalog on the history of insurance in Hartford, CT (1986), 1-2. See also Robert H. Wiebe, The Search for Order, 1877-1920 (New York, 1967); and Olivier Zunz, Making American Corporate, 1870-1920 (Chicago, 1990). 
companies - which promoters of mutual insurance always described negatively as "stock companies" - did not always provide reliable insurance coverage. Fires that consumed rows of adjacent wooden structures in whole blocks and districts occurred regularly in towns throughout the Midwest in the nineteenth century. One result of these fires was high insurance premiums (even for lower risk farm dwellers) and the sudden extinction of companies unable to compensate all claimants. The most egregious national example of company failures occurred after the Chicago fire of 1871, when 68 companies (some from Chicago, some eastern) went out of business. In the year following the Chicago fire, Iowa's state auditor, who was also the state's insurance regulator, ordered thirty-two of seventy "foreign" companies operating in Iowa to stop conducting business in the state. Fifteen of the remaining foreign companies were declared "impaired," but were permitted to continue business. Occasionally, Iowa companies also failed after less famous conflagrations; a costly fire in Burlington in 1838 , for example, caused Iowa's first insurance company to fail. Such failures contributed to the lack of public trust in the insurance industry. ${ }^{5}$

The "valued policy" controversy gave farmers and mutuals further cause to attack stock companies. Farmers and small business owners around the country leveled protests against the standard insurance practice of paying fire claims based on the value of a property prior to a fire rather than on the value enumerated in the policy. That meant that companies often paid claims lower than the value on which premiums had been based. Agitation for "valued policy" legislation increased in the 1870 s and 1880 s. In 1880 Iowa passed a law requiring companies to pay the face value of a total loss; by the end of the decade over half of the states had passed similar laws. Public perception of the companies was damaged because insurance leaders strongly opposed such legislation, claiming that it

5. Henry Giese, Of Mutuals and Men: The Story of the Rise of Mutual Insurance in Iowa (Des Moines, 1955), 32-34; "A City Built on Risk," 1; Census of Iowa for 1905, civ-cvi; J. A. Swisher, "Insurance Comes to Iowa," Palimpsest 21 (1940), 218-28. 
encouraged overinsurance and arson and threatened company solvency. ${ }^{6}$

Iowa farmers also resented eastern insurance companies because they represented a threat to the farmers' sense of local control. Many Iowans had already begun to resent the railroad companies, with their "distant" owners and investors (many of which were life insurance companies), even though railroads brought markets closer, spawning increased demand and production. Similarly, advocates of mutual insurance began to argue that fire insurance companies centered in New York, Hartford, and other urban centers in the United States and Great Britain represented another "distant center" robbing Iowa farmers of a portion of their hard-earned cash.

Promoters of mutual insurance exploited the increasingly organized protest against outside business interests. They pointed out that, in contrast to the stock companies, which were intended to provide a return on investment for a sole proprietor or a group of distant stockholders, mutual insurance associations were established solely for the benefit of members. Those members paid for losses incurred by other members (usually from fire) during a given time period. Instead of advance premiums, members paid periodic "assessments," which equalled each member's portion of total losses incurred by all the members.

This system can trace its roots to fifteenth-century Germany, where a similar risk-sharing structure developed. America's first successful fire insurance company, the Philadelphia Contributionship for the Insurance of Houses from Loss by Fire, founded by Benjamin Franklin and others in 1752, was a mutual. By the

6. H. Roger Grant, Insurance Reform: Consumer Action in the Progressive Era (Ames, 1979), 71-74; Spencer L. Kimball, Insurance and Public Policy: A Study in the Legal Implementation of Social and Economic Public Policy, Based on Wisconsin Records, 1835-1959 (Madison, WI, 1960), 240-49.

7. The average assessment in 1894 was $\$ 1.07$ per $\$ 1,000$ insured. Western Farmers' Institute, July 1894 . To claims of stock companies that the absence of capital in mutuals meant there was no assurance that claims would be paid, one promoter of mutuals replied, "I doubt if there is an intelligent man in Iowa who would not rather have a note signed by 500 Iowa farmers than by a joint stock insurance company." Ibid. 
1820s, farm mutual insurance companies had formed in New Jersey, Pennsylvania, New Hampshire, Connecticut, and Maine. A few mutual insurance organizations were organized by settlers moving into the old Northwest Territory states and Iowa. But only three mutual insurance organizations had formed in Iowa prior to the Civil War, the earliest probably in Scott County. The growth of the mutuals after the Civil War accompanied the increasing resistance Iowa farmers were expressing to the expanding control of national economic forces over their lives. ${ }^{8}$

THE PATRONS OF HUSBANDRY, or Grange, was a major force behind the initial formation and early survival of mutual insurance. The Grange blossomed in Iowa at the time of the Panic of 1873, which sparked a national economic downturn. and provided more evidence to farmers of eastern duplicity contributing to a sense of a loss of local control. In the wake of the Panic of 1873, the Iowa Grange rode a rhetorical wave making it the most successful state organization in the Midwest, attracting one hundred thousand members by $1875 .{ }^{9}$

In its early years the Grange called for farmers to organize economically as well as socially and politically. That made it an important ally for the mutual insurance movement. Both groups emerged at the same time, engaged in joint efforts, and grew in response to the same circumstances. Eastern-owned railroads

8. "History of American Insurance: Mutual Insurance Companies Organized by the Founders of the Republic," Journal of American Insurance (September 1923), 1-5; Giese, Of Mutuals and Men, 10-16; John Bainbridge, Biography of an Idea: The Story of Mutual Fire and Casualty Insurance (Garden City, NY, 1952), 45.

9. Ralph W. Smith, Newton No. 1: The Second Working Grange in the United States and the First in Iowa and the Early Grange Movement in Some Iowa Counties (Newton, 1967), 3-6; Proceedings of the Twenty-Seventh Annual Session of the lowa State Grange (1896), 9. The standard account of the national Grange is Solon J. Buck, The Granger Movement: A Study of Agricultural Organization and Its Political, Economic, and Social Manifestations, 1870-1880 (Cambridge, MA, 1913). More recent accounts include D. Sven Nordin, Rich Harvest: A History of the Grange, 1867-1900 (Jackson, MS, 1974); Thomas A. Woods, Knights of the Plow: Oliver H. Kelley and the Origins of the Grange in Republican Ideology (Ames, 1991); and Donald B. Marti, Women of the Grange: Mutuality and Sisterhood in Rural America, 1866-1920 (Wesport, CT, 1991). On the Grange in Iowa, see Myrtle Beinhauer, "Development of the Grange in Iowa, 1868-1930," Annals of Iowa 34 (1959), 597-618. 
and eastern-owned insurance companies could be castigated in the same breath. The Grange would affix a "seal of condemnation on all forms of fraudulent practices, extortion or robbery, whether done under the form of law, combinations, monopoly or trust methods." As the tenth of the Grange's "ten commandments" admonished,

Thou shalt have no Jewish middlemen between thy farm and Liverpool to fatten on thy honest toil, but thou shalt surely charter thine own ships, and sell thine own produce; and use thine own brains. This is the last and best commandment. . . Choke monopolies, break up rings, vote for honest men, fear God and make money. So shalt thou prosper and sorrow and hard times shall flee away. ${ }^{10}$

The Grange acted on its own admonishment, taking positive steps to give farmers a larger voice in the economic marketplace. "It is the purpose of this great fraternal organization," it claimed, "to increase happiness in all our farm homes and make agriculture more prosperous in all parts of our glorious country." In particular, the Grange championed the notion of farm cooperation for mutual prosperity. Mutual insurance, in fact, was just one of a number of farmer-led cooperative enterprises, such as collective purchasing arrangements, agricultural implement making, creamery and elevator operations, and, later, telephone exchanges. Farm cooperative groups also could champion mutual insurance for a very practical reason: it was usually cheaper than any other form of insurance available at the time. ${ }^{11}$

10. Quotes from Proceedings of the Thirty-sixth Annual Session of the Iowa State Grange (1905); and Roger D. Launius, "The Grange in Decatur County, Iowa: A Representative Study" (unpublished history seminar paper, Graceland College, 1976), 1 (quoting from Oshkosh Weekly Times, 16 December 1874). See also Homer Jones, "The Development and Significance of Mutual Insurance Associations in Iowa," Iowa Studies in Business 3 (October 1928), 7-10, 77; Ross, Iowa Agriculture, 108; Proceedings of the Fourth Annual Session of the Iowa State Grange (1873), 55-56.

11. The detailed, authorized history of farmer cooperatives is Joseph G. Knapp, The Rise of American Cooperative Enterprise: 1620-1920 (Danville, IL, 1969); see also George Cerny, "Cooperation in the Midwest in the Granger Era, 1869 1875," Agricultural History 37 (1963), 187-205; Roy V. Scott, "The Rise of the Farmers' Mutual Benefit Association in Illinois, 1883-1891," Agricultural History 32 (1958), 44-56; and chap. 3, "Cooperative Stores," in H. Roger Grant, Self-Help in the 1890s Depression (Ames, 1983), 59-73. 
Although there is no precise record of the number of mutuals started by Grange members, surviving information about the formation of county and local mutuals often alludes to Grange activism. For example, Iowa's first local Grange, which formed in Jasper County in 1868, organized the Farmers Fire Insurance Company of Jasper County. Its preamble - "Whereas the farming community of Jasper County has felt the necessity of a cheaper and safer fire insurance than that which they now have and also the necessity of retaining, at home, the large sums of money annually taken from them without adequate compensation" - summarized the spirit of both the Grange and mutual insurance. The company admitted any farmer in the county, even if they were not members of the Grange. That first year, 97 farmers took out policies and compensated one Josiah Ives forty dollars for the loss of a colt from lightning. ${ }^{12}$

Other Grange organizations in Iowa tell similar tales of their beginnings. The Decatur County Grange Council organized the Decatur County Fire Insurance Company in 1873 to insure against fire and lightning damage. Three hundred initial policyholders - one-fourth of the county's total Grange membership that year - enlisted in the new company, insuring fifty thousand dollars worth of farm houses and outbuildings. The Chickasaw Mutual Insurance Association likewise began at a regular meeting of the Chickasaw County Council of the Patrons of Husbandry. Formed in New Hampton in 1875, this mutual insured buildings, household furniture, and other personal property against loss by fire or lightning. Its organizers claimed that their rates were one-third of other types of fire insurance. The only loss the first year was due to the death of a horse struck by lightning, bringing in a claim and assessment for \$125. In 1892 an advertisement in the New Hampton Tribune listed among its ten reasons why Chickasaw County farmers should do business with the mutual: "it is a home institution, composed and managed by farmers. ... the money does not go out of the county, but is kept at home. . . while it is safe it is vastly more economical," and farmers won't pay "exorbitant rates charged by stock companies"

12. Smith, Newton No. 1, 25-26. 
or pay for fires in large cities. Most mutuals came into being for similar reasons. ${ }^{13}$

The Grange's embrace of mutual insurance complemented its central message of economic cooperation. By 1873 the Iowa Grange had established a Committee on Insurance which considered plans for a statewide insurance company as well as county or district insurance. During the 1885 annual meeting two other committees went on record promoting the growth of mutual insurance. The Committee on the Good of the Order urged "every patron and all farmers in Iowa to insure their property in Mutual Insurance Companies." The Committee on Co-operative Insurance approved of mutual insurance's increased popularity, predicting its enduring economic value for farmers. That committee, like other farm activists, linked mutual insurance with cooperative endeavors such as collective purchasing, implement making, lumber yards, and creameries. An 1896 Grange report alluded to attempts to disband mutual insurance. The secretary "did what I could to avert the coming evil. Brothers," he cautioned, "do not fail to keep your eyes open, that the wolf does not enter the fold." ${ }^{14}$

The Grange continued to promote mutual insurance, but its influence and much of its interest in economic activities waned after the 1870s. Ineffective leadership and the failure of many of its cooperative enterprises due to undercapitalization and poor management led to disillusionment with the Grange. After peaking at nearly two thousand in the mid-1870s, the number of local Granges in Iowa declined to just 8 in $1885 .{ }^{15}$ Still, mutual insurance survived, thanks to the interest of other groups who continued to appeal successfully to farmers' desires to retain control of their economic destiny.

13. Launius, "Grange in Decatur County," 10-11; Giese, Of Mutuals and Men, 119; New Hampton Tribune, 6 September 1882.

14. Proceedings of the Fourth Annual Session of the Iowa State Grange (1873), 55-56; Proceedings of the Sixteenth Annual Session of the Iowa State Grange (1885), 13-14; Iowa Department of Agriculture, Annual Report (1900), 142; Proceedings of the Twenty-Seventh Annual Session of the Iowa State Grange (1896), 15.

15. Beinhauer, "The Grange in Iowa," 224-26, 228-29. 
MUTUAL INSURANCE ASSOCIATIONS SUCCEEDED in large part because of a localized organizational structure. Mutuals rarely exceeded the boundaries of a county. Members knew each other, and they knew the secretary, the person responsible for the organization's everyday operations. Membership could be denied to an applicant of reputed bad character (such as a drinker), or one whose careless farm operation posed too many fire hazards. ${ }^{16}$

With limited state regulations in effect, mutuals did not all form the same way. Some mutuals were largely the products of the commitment and energy of a single individual, who was usually a known and trusted neighbor. In O'Brien County in northwestern Iowa, for example, J. P. Martin, a locally wellknown Civil War veteran, organized and led the O'Brien County Farmers Mutual beginning in 1890. Martin tirelessly traversed the county on foot, horseback, and sleigh, talking to farmers and extolling the virtues of his mutual insurance company. ${ }^{17}$

Other mutuals were even more directly the products of close ethnic or religious ties. For European settlers in Iowa, mutuals could perform an important mediating function between their (in some ways) insular communities and the expanding market system to which they needed to adapt. Mutual insurance was an extension of ethnic communities. According to one student of the mutuals' growth, "To these people, mutual insurance was more than a business, it was a philosophy. One did not buy a service or a commodity, he was voted into a fraternity." ${ }^{18}$

German settlers, in fact, formed Iowa's first farm mutual in 1849, the Deutsche Brund Gilde. Eventually, they organized twenty-seven other county mutuals with German nationality requirements. Other immigrant groups, including the Swedes (with 6 organizations), Norwegians (3), Danes (2), and Bohemians (5), also adopted this business form, in part at least because it was easier to deal with a local representative and neighbor

16. Matt McCright, "Risky Business: A History of Insurance and Iowa," unpublished manuscript (1989), chap. 1, pp. 1-5.

17. Giese, Of Mutuals and Men, 170.

18. Bainbridge, Biography of an Idea, 167-71; Giese, Of Mutuals and Men, 27-28, $35-43,53-62$. 
who spoke and executed contracts in one's own language than with an outsider using a "foreign" language. ${ }^{19}$

As ethnic communities assimilated, mutuals with ethnic roots broadened their base in order to survive. By the end of World War I, the ethnic flavor of mutuals waned, partly in response to suspicions of non-English speakers in Iowa during the war. Many ethnic mutuals, in fact, changed their names to less ethnic derivatives. The Sweda Mutual Protection Association of Henry County, for example, had insured Swedesburg farmers since 1875. As intermarriages increased, the bylaws changed to admit anyone whose spouse was a Swede. Shortly after World War I the nationality requirement was dropped entirely, and the organization changed its name to the Svea Mutual Fire Insurance Association. Similarly, the German Mutual Aid Association, founded in Fayette County in 1877 by forty-eight German farmers, conducted business in German until 1913, when they converted to English and admitted anyone in the county who farmed and whose risks were acceptable. ${ }^{20}$

At least one mutual combined both Grange and ethnic affiliations. The Swedish Mutual Insurance Association formed in 1865 near the community of Salina in Jefferson County in southeastern Iowa. When a nearby German settler lost all of his belongings in a fire three years later, Christian Kurtz and some fellow German immigrants organized the Germanville Mutual Fire Insurance Company. In 1874 members of the Jefferson County Grange who were dissatisfied with commercial companies' high premiums and their alleged practice of paying for only part of the covered losses organized the Farmers' Mutual Insurance Union of Jefferson County. By 1954 members of the three associations recognized the impracticality of maintaining three fire mutuals in one county, and they merged operations to become the Farmers' Mutual.Insurance Union of Jefferson County. ${ }^{21}$

Some mutuals even formed through existing church ties. The First Maxfield Mutual Insurance Association was orga-

19. Giese, Of Mutuals and Men, 27-28, 35-43, 53-62.

20. Ibid., 121, 126-28.

21. Susan Welty, A Fair Field (Detroit, 1968), 307-9. 
nized in 1860 by congregants of St. John's Evangelical Lutheran Church in rural Bremer County. During its first year the mutual had 101 members. Initially, only church members qualified to join the mutual. Later, non-members were allowed to join if existing members deemed them to be good citizens. A committee appraised losses and conducted business by oral agreement until 1867, when formal bylaws were adopted for the First German Fire Insurance Company of Maxfield. Members had to reside within twelve miles of the church and pay a fifty-cent membership fee. During the next thirty years, the mutual increased its territory to include four other counties. ${ }^{22}$

Local success stories such as these led to a growing acceptance of the viability of mutual insurance. That acceptance was reflected in some remarks made by the state auditor in 1880 , two years after Iowa mutuals were required to report their finances to his office. "I believe I am but serving the public interest," wrote State Auditor W. V. Lucas, "when I say in this report that the mutual association plan of insurance is as good for the farmers of Iowa as any other, and so much cheaper that it ought to be thoroughly considered." ${ }^{\prime 23}$

IN THE 1890s support came from another influential source when "Uncle Henry" Wallace, a farm editor of considerable prestige, embraced the mutual movement with evangelistic fervor. For two years beginning in 1896, Wallace wrote weekly articles for his paper, Wallaces' Farmer, championing mutual insurance and promoting its growth. He even created a section of the paper devoted exclusively to mutual insurance. That section, he claimed, was "one of [the paper's] regular and most important features." Wallace justified the decision by noting that "Wallaces' Farmer endeavors not only to take an interest but to lend its efficient aid to everything that is calculated to promote the prosperity of the farmer, the security of his property, and the lessening of his burdens." In return for Wallace's support, a state association of mutual insurance associations

22. Inventory of the Records of the Mutual Insurance Associations of Iowa, box 4, Parks Library, Iowa State University.

23. Quoted in Giese, Of Mutuals and Men, 51. 
unanimously voted to name his paper the official paper for mutual insurance. ${ }^{24}$

Wallace printed effusive endorsements from various county organization heads and the recently formed statewide mutual associations. No testimonial was more impassioned than the words flowing from Wallace's pen as he urged his readers to become members of mutuals in their environs. "Mutual insurance," he wrote in 1897, "had never been thought of until man had attained an advanced stage of civilization. ... I do not see how mutual insurance is possible in a country not permeated and dominated by Christian ideas and where the doctrine of the brotherhood of man and the obligation of mutual helpfulness is not more or less generally recognized and acted upon." The former Presbyterian minister further proclaimed that mutual insurance represented "that spirit of altruism or love of our neighbor that grows out of a recognition of the scriptural motto: 'Seek not every man his own, but every man his brother's wealth.'"25

Wallace repeatedly urged his readers to buy insurance from mutuals and to form new ones where none existed. In January 1897 he made an offer to the five counties in Iowa that still had no mutuals. At the newspaper's expense he would send a person versed in mutual insurance law and organization to any gathering of farmers in those five counties. The goal, of course, was to create mutuals for the farmers in those counties. Wallace also joined with mutual insurance companies to set up a tent at the 1897 state fair in Des Moines. The tent, described as headquarters of both the newspaper and the mutual insurance companies, was to be "an elegant place to drop in at any time during the Fair and meet with the leading insurance people of the state." 26

Wallace's promotion of mutual insurance probably helped to solidify the movement's status. His support also indicates

24. Wallaces' Farmer and Dairyman, 27 November 1896. On "Uncle Henry" and his prominence, see Richard S. Kirkendall, Uncle Henry: A Documentary Profile of the First Henry Wallace (Ames, 1993).

25. Wallaces' Farmer and Dairyman, 12 March 1897.

26. Ibid., 15 January 1897. 
how the movement looked both forward and backward. Wallace was, as one historian put it, "simultaneously a nostalgic agrarian and an advocate of scientific agriculture." His advocacy of mutual insurance was but a part of his larger agenda of promoting the organization of rural life on a rational, scientific basis, while at the same time seeking to preserve the essential traits of America's agrarian communities. ${ }^{27}$

BY THE TURN OF THE CENTURY, then, an ideological and structural foundation for mutual insurance had been laid. Iowa had a statewide network of mutual companies with varied local support, coupled with endorsements from leading agricultural institutions and insurance leaders. In 1869 only about a halfdozen mutuals had existed in Iowa. That figure jumped to 33 by 1875 when Grange activities began. From the early 1870 s until the mid-1890s, new mutuals formed in Iowa at a strong pace. ${ }^{28}$ In 1894 the state auditor identified 137 mutual associations in the state. Contributors to the Western Farmers' Institute, choosing to see the glass as two-thirds empty rather than onethird full, estimated at that time that "not one-third" of Iowa's farmers insured with mutuals, and "very few indeed are the counties that have entirely captured the field. ${ }^{29}$ Some counties came close. Washington County's mutual had 2,347 members in 1898. (The next year the State Agricultural Society recorded 2,173 total farms in the county.) Floyd County had 1,500 mutual members in 1897 out of 1,963 total farmers in the county. By contrast, some county organizational efforts seem to have stirred little interest in mutual insurance. One of three mutuals in Dubuque County (the other two were at the community or township level) indicated $\$ 800,000$ insurance in force in 1897 ,

27. David B. Danbom, The Resisted Revolution: Urban America and the Industrialization of Agriculture, 1900-1930 (Ames, 1979), 43. See also Kirkendall, Uncle Henry, 5-8.

28. Jones, "Development of Mutual Insurance Associations," 23. We can determine the total number of mutual organizations but not the number of members or the total business in a particular geographic area. We can only piece together scattered data and estimates made by insurance promoters.

29. Western Farmers' Institute, July 1894. 
while the total value of farm property the following year was listed at \$14 million. Winnebago, Sioux, Calhoun, Fayette, and Lyon Counties offer similar gaps between the mutuals' insurance in force and farm property values. An even greater contrast appears in Palo Alto County, whose mutual began in 1886 . Twelve years later, only 338 policies (presumably covering individual farms) were in force out of a total of nearly fifteen hundred farms in the county. ${ }^{30}$

In 1899 the secretary of the Cerro Gordo County Mutual summarized the short history of farm mutuals.

The co-operative insurance idea was conceived in weakness, was born in adversity, has been cultivated through trial and tribulation and its strength still has to be nurtured through an opposition that would paralyze the best efforts of any people in any other enterprise. The system has proven cheap and effective when administered with the honesty that comes with simplicity. ... Its principles are abiding, resting upon the honor of friends .... and anchored to the 'Golden Rule.'

The state auditor agreed. "I do not recall an instance where a Mutual company has failed to make payment of a loss," he assured a gathering of mutual insurers in 1894. "I do hear many complaints from other companies failing. I concur in the idea that money should be kept at home. I believe that your institution has come to stay and fill a large field of usefulness. ${ }^{\prime 11}$

This ideological and institutional stability made possible an important new organizational development in the mutual insurance story: mutuals began to organize on a broader basis to offer additional financial security and political influence and more specialized coverage. As the mutuals grew and adopted many of the industry's standard administrative practices, their leaders were able to sustain the barrage of populist rhetoric because their main arguments remained essentially true. Premium monies collected by the mutuals still remained in the

30. Wallaces' Farmer and Dairyman, 22 January, 16 July, 10 December 1897, 25 February, 4 March 1898; State Agricultural Society, Annual Report (1899), 139-41.

31. Quotes from Virginia Wadsley, Bear Ye One Another's Burdens: The First 100 Years of Farmers Mutual Hail Insurance of Iowa (Des Moines, 1993), 23; and Giese, Of Mutuals and Men, 52. 
locales of the insured, rather than in the pocketbooks of out-ofstate stockholders. Perhaps most importantly, an increasingly complex business structure was still economical enough to allow mutuals to offer lower policy rates than their competitors, helping to ensure the survival and prosperity of the mutuals.

In the 1880s local mutual leaders had already formed a statewide organization of county mutuals, the Iowa Mutual Insurance Association. This group - one of the first of its type in the nation - began when M. Farrington of the Bremer County Mutual and a state Grange leader called an organizational meeting in Des Moines. Eighteen Iowa mutuals sent representatives to the first meeting, and membership increased in succeeding years. The association's main accomplishments in the early years involved legislation related to mutual insurance. A key legislative achievement was securing legislation enabling the creation of statewide mutuals. The original legislation authorizing statewide mutuals only allowed them to cover loss by fire or death. In 1884 the legislature allowed statewide mutuals to extend coverage to other risks, such as tornadoes, windstorms, lightning, and hail. ${ }^{32}$

Tornadoes are a particularly serious problem in Iowa. Although some county mutuals did insure against wind damage, many thought - probably correctly - that wind coverage was too risky. A powerful storm sweeping through a county could threaten the solvency of a county organization, forcing very high assessments. Carrying the risk statewide, some reasoned, could mitigate the chances of a company's failure to meet claims. Spreading the risk among more members seemed the only practical way to insure against wind damage. As one promoter put it, "The reason why the County Mutuals do not insure against tornadoes is that the territory is too small. A single blast might slick out the whole county and scarcely any

32. Giese, Of Mutuals and Men, 244-45; Laws of Iowa (1884), chap. 11. The original legislation regulating mutual insurance associations limited to two hundred the number of persons who could incorporate to make "mutual pledges and [give] valid obligation to each other for their own insurance from loss by fire." Laws of Iowa (1868), chap. 138. That limit was raised to seven hundred in 1870 . Ibid. (1870), chap. 108. The limit was removed entirely in 1878, making possible statewide mutuals. Ibid. (1878), chap. 104. 
one left with enough to help meet the losses, while with the State company the expense is very trifling. ${ }^{\prime 33}$

Jesse B. Herriman, a Fayette County farmer, was willing to try putting the theory into action. In 1884 he launched the lowa Mutual Tornado, Cyclone and Windstorm Insurance Association (currently called IMT Insurance Company). Herriman had become involved in mutual insurance by serving as secretary of the highly successful Fayette County Farmers Mutual Insurance Association, and he had been active in the formation of the state association. When he began IMT, Herriman covered twenty counties in northeast lowa. Within a few months the association went statewide. Drawing from the statewide network of mutuals, IMT, unlike the local mutuals, advertised extensively to gain policyholders and remunerated local mutual secretaries who sold windstorm policies. IMT even produced bylaws in German and Norwegian to appeal to members of ethnic county mutuals. ${ }^{34}$

In part because of quiet winds during the first fourteen years of its existence, the company prospered, becoming what was reportedly the largest mutual tornado insurance company in America. Yet Herriman continued to insist that the company was "simply a benevolent institution conducted on business principles, giving insurance at actual cost." In 1898 the company passed its first solvency test. During that especially turbulent year, tornadoes destroyed several Iowa communities. The company's payment of all claims to its policyholders boosted IMT's reputation. By 1899 IMT could claim about fifty thousand Iowa policyholders (out of 204,000 Iowa farms) with $\$ 48$ million of insurance in force. The statewide mutual concept had succeeded with its first experiment. ${ }^{35}$

33. Western Farmers' Institute, March 1894.

34. IMT Centennial, 1884-1984 (Des Moines, 1985).

35. Western Farmers' Institute, May 1894; Bainbridge, Biography of an Idea, 180-81; Jones, "Development of Mutual. Insurance Associations," 52-57; Giese, Of Mutuals and Men, 200-207; IMT Centennial. Actually, an earlier statewide mutual appeared in Iowa in 1875, but it was not designed for farmers. In an effort to fight exorbitant costs for fire insurance for grain mills, James Sharp, a Wilton mill owner, organized the Mill Owners Mutual Fire Insurance Company of Iowa through the Iowa Millers Association. His successful company, the first of its kind in the nation, cut premium costs by 42 percent over stock companies and expanded beyond Iowa's borders in the $1890 \mathrm{~s}$. 
The second statewide mutual for farmers was begun by a man awed by the destructive power of hail. As a teenager living in northwest Iowa, Walter Rutledge had witnessed bark skinned from trees and a grove of cottonwood trees destroyed by hail. After stints as a schoolteacher and secretary of a local Farmers' Alliance, Rutledge became manager of the Sac County Mutual Farmers Fire Insurance Association in 1892. He plunged into his new career with the enthusiasm of a convert. Almost immediately he became active in the state association, where at an annual meeting he heard debates about the feasibility of hail insurance. State association representatives doubted the actuarial practicality of creating a statewide organization. Rutledge disagreed. The Farmers Mutual Hail Insurance Association of Iowa, which he formed in 1893, surprised the skeptics and, like IMT, continues to operate today. ${ }^{36}$

To promote his new company - and mutual insurance in general-Rutledge founded a monthly farm newspaper, the Western Farmers' Institute, published in his home town of Early, Iowa. Ostensibly, the paper was "devoted to making the Farm pay by the Intelligent Application of Sound Agricultural Theories in all departments of Farm Work," but every issue gave prominent and extensive play to contributions from promoters of mutual insurance, reporting the economic benefits, amazing growth, and sound financial condition of farm mutuals.

The paper included articles and letters from Rutledge's friends and associates attacking the stock companies that they considered their chief rivals. Their contributions reflect their mastery of the rhetoric that sustained the mutual insurance movement, even as the movement itself began to move away from its roots. One of Farmers' Mutual Hail's advertisements in the paper traced the origins of the movement to the Grange, which "had its mission of bringing out the farmer." "The Alliance," the ad continued, "has been an educator of magnificent proportions, but it has been left for our Farm Mutual Insurance

36. Walter Rutledge, "Farmers Mutual Hail," unpublished manuscript, 1938; additional information gleaned from materials gathered in company archives currently being organized. See also Wadsley, Bear Ye One Another's Burdens, 7-8, 26-37. 
Associations to save ourselves more money than has ever been accomplished by any other means." An article the following month offered one of many critiques of the effects of large corporations on American society. "The American people have done enough," the contributor proclaimed, "by the way of building up institutions to such enormous proportions and influence, that they are able to defy and make slaves of their creators. These companies as well as some other institutions that have been over fostered are now so far beyond the control of the people that the only human agency left to us to protect ourselves from this avarice is co-operation. ${ }^{137}$

Repeatedly, contributed items compared mutual rates to higher stock company rates, showing the savings that could be made by eliminating most administrative costs. A contributor to the first issue concluded one such comparison by asking rhetorically, "One hundred and fifty per cent of the loss does seem a little steep for administrative expenses, don't it?" Finally, contributors were eager to portray an image that combined a sense of self-reliance with a spirit of communal burden sharing. "Only a few years ago," according to a speaker at the state association meeting of 1894 whose remarks were published in the paper, "we were at the mercies of foreign stock companies to aid us - should we become a victim of either of the great destroyers. Today how different. ... we cheerfully come to the rescue of any of our members. . . . Had the stock companies dealt fairly with us as a farming community there probably would have been very few of our 134 farmers' insurance companies organized. ${ }^{\prime 38}$

The Western Farmers' Institute did not long survive, but its goal of promoting mutual insurance to progressive farmers was picked up in 1896, as we have seen, by Wallaces' Farmer. Its editor, "Uncle Henry" Wallace, also worked with Walter Rutledge and other mutual insurance leaders to form a national association of mutuals in 1895. The association's objective was to promote the growth and usefulness of cooperative mutual insurance in the United States. Wallace announced its formation

37. Western Farmers' Institute, March 1894, April 1894.

38. Ibid., March 1894, April 1894. 
and printed meeting agendas and minutes. Started in Rutledge's office in Des Moines, other Iowans played leading roles in the institution, providing key officers in the early years. ${ }^{39}$ They had come full circle. Originating in opposition to national institutions, Iowa's mutual insurance leaders now found advantages in organizing themselves nationally.

BY THE TURN OF THE CENTURY, mutual insurance was firmly entrenched in the Iowa farm economy. In fact, it lasted longer than some of the organizations that gave the mutuals their impetus. According to a 1921 study, roughly half of Iowa's insurable farm property was insured by mutuals. ${ }^{40}$ Iowa was, in fact, a leader in the development of local mutuals. When the national association formed in 1895, for example, Iowa had 153 companies, just behind Illinois with 187 and Wisconsin with 158 . Other midwestern states had far fewer mutual organizations: Nebraska had 41, Michigan 39, Ohio 30, Missouri 21, and Kansas 9.11

Two innovations after the turn of the century carried mutual insurance further along its evolutionary path. Along with devising more sophisticated actuarial standards, insurers launched the concept of reinsurance for farmers and began efforts to mitigate losses.

Concerned that unusually severe calamities, such as the total loss of a large farmhouse or two, could severely strain the resources of a local mutual, forcing a very high assessment, and potentially shaking the confidence of mutual members, the Iowa Mutual Association began to discuss reinsurance in 1899 as a

39. Wadsley, Bear Ye One Another's Burdens, 37.

40. Inventory of the Records of the Mutual Insurance Associations of Iowa, box 4 . By the 1920 s mutuals had reached a saturation point of about 162 mutuals, which assumed about 30 percent of the total property insurance business in the state, and probably a much higher percentage of farm property. Unfortunately, the way the state collected statistics on insurance coverage makes it impossible to give an accurate figure. Jones, "Development of Mutual Insurance Associations," 83.

41. Wallaces' Farmer and Dairyman, 19 February 1897; Harry P. Cooper, Lest We Forget: A Brief History of the Indiana Farmers Mutual Insurance Company (Indianapolis, 1937), 303-8. 
way of mitigating such risks, by, in effect, insuring insurance companies. Ten years later, the state association created the Iowa Farmers Mutual Reinsurance Association (later called Grinnell Mutual Reinsurance Company), which may have been the first company of its kind for farmers in the nation.

Initially, only twenty-seven county mutuals joined the organization, which struggled with limited assets for its first twenty-five years. Then, in the 1930s, Grinnell Mutual, working closely with Iowa Mutual Tornado, embarked on a new operating course that helped its growth and credibility with the farm community. The organization hired agricultural engineer Henry Giese of Iowa State University to establish an inspection service that was available to member county mutuals. Its purpose was to stem a growing number of farm fire losses that occurred during the Great Depression. By 1958, Giese's service had inspected 205,000 farm buildings and effected alterations in more than 100,000 of them. This loss control approach was adopted by Farmers Mutual of Nebraska in the 1930s. ${ }^{42}$

THE MUTUAL MOVEMENT IN IOWA is a legacy of the spirit of farm cooperation espoused by earlier generations of farm organizers and reformers. Mutuals stood as an integral part of the expanded market economy that Iowa farmers increasingly participated in during the last quarter of the nineteenth century. Ultimately, it was the mutuals' practical benefits - particularly the cheaper rates they were able to offer to farm consumersrather than their rhetoric that enabled them to make the transition from the passing agendas of early farm organizations and the neighborliness and strict ethnic affiliation of the early mutual associations to the large, corporate organizations they became during the twentieth century.

42. Gene F. Rutledge, The Feeling is Mutual (Des Moines, 1980), 8; Jim George, Working Together: Grinnell Mutual, The First 75 Years (Montezuma, 1982); Jim George, interview with author, Grinnell, June 1990. Giese delivered many papers at mutual insurance meetings around the country in the 1940s and 1950 s. He also spawned fire prevention studies by students at lowa State College. Several of Giese's papers were published as Iowa Agricultural Experiment Station Bulletins. Giese also recorded the history of the rise of mutual insurance in Iowa in Of Mutuals and Men. 
Copyright of Annals of Iowa is the property of State of Iowa, by \& through the State Historical Society of Iowa and its content may not be copied or emailed to multiple sites or posted to a listserv without the copyright holder's express written permission. However, users may print, download, or email articles for individual use. 